\title{
Use of the Glomus etunicatum as biocontrol agent of the soybean cyst nematode
}

\author{
Uso do Glomus etunicatum como agente de biocontrole do nematóide de cisto da soja \\ Uso del Glomus etunicatum como agente de biocontrol del nematodo del quiste de la soja
}

Received: 04/16/2021 | Reviewed: 04/23/2021 | Accept: 05/07/2021 | Published: 05/21/2021
Tatiana Benedetti
ORCID: https://orcid.org0000-0003-3066-8805
University of Passo Fundo, Brazil
E-mail: benedettitatiana@ @otmail.com
Zaida Inês Antoniolli
ORCID: https://orcid.org/0000-0003-2036-8710
University Federal of Santa Maria, Brazil
E-mail: zantoniolli@ @mail.com
Elisangela Sordi
ORCID: https://orcid.org/0000-0003-3464-8326
University of Passo Fundo, Brazil
E-mail: elisangelasordi@hotmail.com
Ivan Ricardo Carvalho
ORCID: https://orcid.org/0000-0001-7953-7879
E-mail: carvalho.irc @gmail.com
Edson Campanhola Bortoluzzi
University regional northwestern of the state of Rio Grande do Sul, Brazil
ORCID: https://orcid.org/0000-0002-0967-0057
University of Passo Fundo, Brazil
E-mail:edsonb@upf.br

\begin{abstract}
This study investigated the effect of arbuscular mycorrhiza (Glomus etunicatum Becker \& Gerd.), on the cyst nematode (Heterodera glycines Ichinohe), in a greenhouse. Mycorrhizal and non-mycorrhizal soybean plants were exposed to the pathogen at different initial population densities $(0,500,1000,2000$, and 4000 nematodes eggs). Soybean growth, nematode reproduction, and the arbuscular mycorrhizal fungus's capacity to decrease disease pressure were determined after 60 day-olds. The height of the plants was increased by $26 \%$ in the presence of arbuscular mycorrhizal fungus (AMF) despite of a higher initial population of cyst nematodes. The root length was, on average, $32.20 \%$ was greater in the presence of AMF. The number of nematodes females found in the root system of mycorrhizal plants was $28.21 \%$ lower than in non-mycorrhizal roots. These results suggest that AMF G. etunicatum acts indirectly, promoting an improvement in the nutritional plant status creating tolerance to the presence of the pathogen by soybean.
\end{abstract}

Keywords: Biological control; Heterodera glycines; Glomus etunicatum; Mycorrhizal fungi.

\section{Resumo}

Este estudo investigou o efeito da micorriza arbuscular (Glomus etunicatum Becker \& Gerd.), no nematóide de cisto da soja (Heterodera glycines Ichinohe) em casa de vegetação. Plantas de soja micorrizada e não micorrizada foram expostas ao patógeno em diferentes níveis de densidade populacional inicial $(0,500,1000,2000$ e 4000 ovos de nematóides). O crescimento da soja, a reprodução do nematóide e a capacidade do fungo micorrízico arbuscular em diminuir a pressão da doença foram determinados após 60 dias da emergência das plantas. A altura das plantas foi aumentada em $26 \%$ na presença de fungo micorrízico arbuscular (FMA) apesar do alta população inicial do nematóides de cisto. O comprimento da raiz foi, em média, 32,20\% maior na presença de FMA. O número de fêmeas do nematoide encontradas no sistema radicular das plantas micorrizadas foi $28,21 \%$ menor do que nas raízes não micorrizadas. Esses resultados sugerem que AMF G. etunicatum atua de forma indireta, promovendo uma melhora no estado nutricional da planta e criando tolerância à presença do patógeno na soja.

Palavras-chave: Controle biológico; Heterodera glycines; Glomus etunicatum; Fungos micorrízicos.

\section{Resumen}

Este estudio investigó el efecto de la micorriza arbuscular (Glomus etunicatum Becker \& Gerd.), el nematodo del quiste (Heterodera glycines Ichinohe) en un invernadero. Plantas de soja micorrízicas y no micorrízicas se expuso al patógeno en diferentes niveles de densidad poblacional inicial $(0,500,1000,2000$ y 4000 huevos de nematodos). Después de 60 días se determinó el crecimiento de la soja, la reproducción de nematodos y la capacidad del hongo micorrízico arbuscular para disminuir la presión de la enfermedad. La altura de las plantas se incrementó en un 26\% en presencia de hongo micorrízico arbuscular (HMA) a pesar de la alta poblacion inicial de nematodos quísticos. La longitud de la raíz fue, en promedio, 32,20\% mayor en presencia de HMA. El número de hembras de nematodos 
encontradas en el sistema radicular de las plantas micorrízicas fue 28,21\% menor que en las raíces no micorrízicas. Estos resultados sugieren que AMF G. etunicatum actúa indirectamente, promoviendo una mejora en el estado nutricional de la planta y creando tolerancia a la presencia del patógeno em la soja.

Palabras clave: Control biológico; Heterodera glicinas; Glomus etunicatum; Hongos micorrízicos.

\section{Introduction}

Nematodes constitute a diverse group of soil organisms. Plants and animals have free-living genera and parasitic genera (Ferraz \& Brown, 2002). Plant-parasitic nematodes are classified as endoparasites or ectoparasites based on their parasitism strategy (Perry \& Moens, 2001). Ectoparasites use their stiletto to acquire food from the cells of the epidermis or root cortex, while endoparasites enter completely into the root cells and feed within the roots of the host plant. Endoparasites have the most complex feeding strategy among phyto-parasites. They select cells in the central root cylinder, converting them into feeding sites and making them their habitat and food source (Gheysen \& Mitchum, 2011). This last group includes cyst nematodes, which, together with root gall nematodes, are considered the parasites most harmful to agricultural plants in the world (Bartlem et al., 2014; Ibrahim et al., 2019; Jones et al., 2013). They can cause significant damage to crop (Wesemael et al., 2011). Estimates indicate that nematode disease causes more than one billion dollars of productivity losses per year in American crops alone (Koenning \& Wrather, 2010).

Among the species of cyst nematodes most damaging to crops are the cereal cyst nematode (Heterodera avenae Wollenweber), which causes damage at an estimated rate of $20 \%$ to $90 \%$ in wheat and oats in different locations in the world (Toumi et al., 2018; Wu et al., 2014), and the soybean cyst nematode (Heterodera glycines Ichinohe), which is one of the most devastating soybean pests (Glycine max (L.) Merril) (Guo et al., 2020). The latter species of nematode produces a survival structure known as a cyst, which consists of the female's body and contain hundreds of eggs protected by a layer of cuticle. Eggs inside cysts can survive in the soil for more than 10 years and produce viable nematodes (J2) under favorable conditions (Haarith et al., 2020). Production losses caused by plant-parasitic nematodes tend to increase due to changes in climate and intensified production systems (Nicol et al., 2011). Studies show that the density of cyst nematodes increases after consecutive years of soybean monoculture, correlating with the decline in crop productivity (Grabau \& Chen, 2016; Strom et al., 2020). The use of nematicides to control nematodes has also been limited due to increased concerns about human health and environmental sustainability, which have led to the prohibition of several chemical molecules (Hol \& Cook, 2005; Schouteden et al., 2015).

New nematicide alternatives are being studied (Ruanpanun \& Chamswarng, 2016; Wesemael et al., 2011). Several organisms have been tested as potential cyst nematode biocontrol agents, including certain fungi and bacteria (Haarith et al., 2020). One of these new nematicide alternatives is arbuscular mycorrhizal fungi (AMFs), which are obligatory symbionts that can protect their hosts against stress factors, such as plant parasitic nematode infections (Schouteden et al., 2015). There is a consensus in the literature that AMFs can improve host tolerance and increase plant resistance to nematode attacks (Gianinazzi et al., 2010; Hol \& Cook, 2005; Pozo \& Azcón-Agiilar, 2007; Rasmussen et al., 2019; Schouteden et al., 2015; Singh et al., 2011; Vos et al., 2012; Whipps, 2004). Microorganisms are promising alternative nematode biocontrol agents (Alban et al., 2013; Haarrith, et al., 2020; Hol \& Cook 2005; Ma et al., 2017; Nimnoi et al., 2020; Ruanpanun et al., 2016;). However, much remains to be studied regarding the mechanisms of this biocontrol (Herrejón-Alvarado et al., 2019). AMFs may have direct effects on the pathogen through competition for space or nutrients, or indirect effects through better plant nutrition or increased root system resistance (Gianinazzi et al., 2010; Sohrabi et al., 2020). These different mechanisms cannot be considered completely independent, as biocontrol probably results from a combination of them (Cameron et al., 2013).

Technological advances in science, such as the genome sequencing of some nematodes (Abad et al., 2008; Cotton et al., 2014) and of some host plants, such as soybeans (Scmutz et al., 2010), have improved the understanding of the 
mechanisms involved in these AMF effects (Schouteden et al., 2015). Greater attention has also been paid to the interactions between plant roots and microorganisms (De Coninck et al., 2015) and to the biotic and abiotic factors involved in this process. Thus, this work aimed to evaluate the potential of mycorrhizal fungus Glomus etunicatum as a biocontrol agent of the cyst nematode $(H$. glycines race 3$)$ in soybeans.

To that purpose, this study evaluated the response of soybean plants mycorrhized with G. etunicatum comparatively with non-mycorrhized soybean plants to the presence of different pressure levels of the soybean cyst nematodes.

\section{Methodology}

The research was descriptive-explanatory, since it characterized and compared the effect of arbscular mycorrhiza in the control of cyst nematodes, using experimental procedures, in the field and in the laboratory. As for nature, it is a quantitative research (Silveira \& Córdova, 2009).

Soybean seeds of cultivar BRS 154 superficially disinfected in $2.5 \% \mathrm{NaOCl}$ for 2 minutes were pre-germinated in autoclaved sand at $121^{\circ} \mathrm{C}, 0.15 \mathrm{Mpa}$, for 120 minutes. The seeds were inoculated with $4 \mathrm{ml}$ of a cell suspension (about $1 \times 106$ $\mathrm{ml}$ ) of Bradyrhizobium elkani, strains Semia 587 and 5079 (CPAC 15).

The H. glycines inoculum was obtained from Embrapa wheat growing in Passo Fundo, the Rio Grande do Sul. A nematode egg solution was prepared by suspending $100 \mathrm{~cm}^{3}$ of soil in water and pouring the suspension through 25 and 100 $\mu \mathrm{m}$ mesh sieves. The material retained in the $100 \mu \mathrm{m}$ sieve was macerated over a $500 \mu \mathrm{m}$ sieve and the retained material was collected and counted in a Peters chamber using an optical microscope. The egg concentration was adjusted according to the treatments necessary for inoculation of the plants.

The nematode inoculation was conducted at the time of transplanting pre-germinated soybean seedlings into a substrate containing the inoculum of the AMF Glomus etunicatum. This transplanting occurred 10 days after soybean germination, and G. etunicatum was chosen because it is the most common AMF species in soybean-producing soils (Khalil et al., 1992; Winkler et al., 1994). The treatments, which included samples with and without soybean cyst nematodes and with and without the presence of G. etunicatum, were distributed in a completely randomized design, with 10 treatments and six repetitions. Fifteen days after emergence, the seedlings were transplanted to $500 \mathrm{~g}$ ceramic pots containing a substrate composed of a 2:1 (v/v) mixture of sand and soil (23\% clay and $1.2 \%$ organic matter). The soil $\mathrm{pH}$ in water was $\mathrm{pH} 6.5$, and the soil contained $\mathrm{Al}$ at $0.0 \mathrm{cmolc} \mathrm{L}^{-1}, \mathrm{P}$ at $7.2 \mathrm{mg} \mathrm{L}^{-1}, \mathrm{~K}$ at $42 \mathrm{mg} \mathrm{kg}^{-1}$, and $\mathrm{Ca}$ at $7.4 \mathrm{cmolc} \mathrm{L}^{-1}$. The substrate was sterilized in an autoclave at $121^{\circ} \mathrm{C}, 0.15 \mathrm{Mpa}$, for $120 \mathrm{~min}$. The substrate was inoculated with $1 \mathrm{~g}$ of G. etunicatum spores at a concentration of 120 spores $\mathrm{g}^{-1}$, according to treatments. The plants were kept in the greenhouse for 60 days and irrigated weekly with $10 \mathrm{~mL}$ of a nutrient solution containing $1.2 \mathrm{mg} . \mathrm{kg}^{-1} \mathrm{ZnCl}_{2}, 0.4 \mathrm{mg} \cdot \mathrm{kg}^{-1} \mathrm{H}_{3} \mathrm{BO}_{3}, 0.2 \mathrm{mg} \cdot \mathrm{kg}^{-1} \mathrm{MnCl}_{2} .4 \mathrm{H}_{2} \mathrm{O}, 0.01$ $\mathrm{mg} . \mathrm{Kg}^{-1}\left(\mathrm{NH}_{4}\right)_{6} \mathrm{Mo}_{7} \mathrm{O}_{24} \cdot 4 \mathrm{H}_{2} \mathrm{O}$, and $9.0 \mathrm{mg} \cdot \mathrm{Kg}^{-1} \mathrm{~K}_{2} \mathrm{SO}_{4}$.

The evaluations were carried out after sixty days. The number of female nematodes in the plant root systems was determined using the method of Tihohod \& Santos (1993) and counting with a microscope. The number of cysts in the soil was assessed using $100 \mathrm{~cm}^{3}$ of soil placed in a container and flooded with running water to wash out the cysts. The solution was poured through a set of 25 and $100 \mu \mathrm{m}$ sieves and the retained material was collected on paper towels in Petri plates. The cysts were counted using a microscope.

Plant height and dry mass were also measured. For dry mass analysis, the aerial part of the plant was detached at the soil level and dried in an oven at $65 \mathrm{oC}$. The dried material was then weighed for determination of the mass. The root length was determined by measuring the length of the primary root from the region of the root-shoot junction to the root tip.

The plant height and root length data were subjected to analysis of variance, with the averages compared by the Tukey test at a 5\% probability of error. The numbers of cysts and females in the roots were analyzed by regression analysis. For these 
analyses, the data obtained from the evaluations were transformed (square root of $X+0.5$ ) to reduce the heterogeneity of the variance. The relationship between the population density of cyst nematode in the treatments with and without AMFs was compared using polynomial regressions.

\section{Results and Discussion}

The beneficial action of the mycorrhizal association with Glomus etunicatum was evident by the development and health of the treated soybean plants (Figure 1). Several authors have described the efficiency of these fungi in reducing the severity of various diseases (Dehne, 1982; Vos et al., 2012; Rasmussen et al., 2019).

Figure 1 - Action of the fungus Glomus etunicatum on soybean plants, 20 days old, growing in a greenhouse. A = plants infected with 2000 eggs from the cyst nematode Heterodera glycines

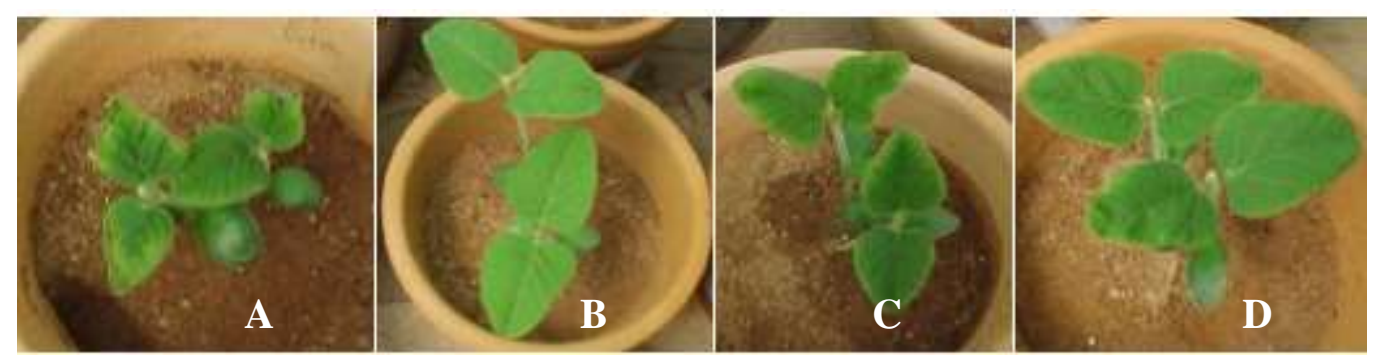

B = plants inoculated with G. etunicatum and then infected with 2000 cyst nematode eggs. $C=$ plants treated with 4000 eggs from the cyst nematode. $\mathrm{D}=$ plants inoculated with G. etunicatum and then infected with 4000 cyst nematode eggs. Source: Authors.

The presence of AMF increased the plant height by $6.93 \%$ (Table 1). AMFs are known to have a stimulatory effect on plant growth, including that of soybeans, because of improved P nutrition and water transport (Baum et al., 2015; Parniske, 2008). This increase in height was also in agreement with the findings of Ceustermans et al. (2018), who also found increases in plant growth and weight in the presence of AMFs. Similarly, Hol \& Cook (2005) found an average increase of $8 \%$ in plant height in response to AMFs in plants under attack by cyst nematodes. In the present study, plants treated with a high level of cyst nematode inoculum were $26 \%$ shorter in height, on average, in the absence than in the presence of AMFs (Table 1 ). This result was similar to that reported by Todd et al. (2001), who found a decrease of $29 \%$ in the average plant weight in the presence of the nematodes and an increase of $36 \%$ in the average plant weight in the presence of an AMF.

Table 1 - Effect of the arbuscular mycorrhizal fungus (Glomus etunicatum) on the height of 60-day-old soybean plants infected with the soybean cyst nematode (Heterodera glycines) under greenhouse conditions.

Height plant (cm)

Number eggs

\begin{tabular}{ccc} 
& Without FMA & With FMA \\
\hline 0 & $29.34 \mathrm{a}$ & $29.64 \mathrm{a}$ \\
500 & $23.52 \mathrm{ab}$ & $20.20 \mathrm{ab}$ \\
1000 & $20.22 \mathrm{ab}$ & $20.38 \mathrm{ab}$ \\
2000 & $16.90 \mathrm{~b}$ & $26.80 \mathrm{ab}$ \\
4000 & $15.68 \mathrm{~b}$ & $15.96 \mathrm{~b}$ \\
\hline
\end{tabular}

The averages in the column do not differ by the Tukey test ( $\mathrm{p}<0.05$ probability of error). Source: authors.

The stimulatory effect of AMFs on the growth of soybean plants may be a result of an increase in plant nutrition; 
however, some studies have indicated that the suppression of cyst nematodes by the presence of AMFs occurs due to biological phenomena and not just nutritional improvement (Cameron et al., 2013; Schouteden et al., 2015). This suppression of the nematodes may be a consequence of competition for nutrients and space between organisms (Vos et al., 2014). AMFs rely on photosynthesis from the host in the early stages of development for root colonization. This period of intense biosynthesis by the AMFs can also coincide with the period of initial establishment of the nematode feeding sites. Since the fungus requires at least 10 days to establish itself at the root (Kellam \& Shenck, 1980), an insufficiency of nutrients could result in decreased nematode reproduction. This competition for nutrients, with an emphasis on carbon, has been suggested as an AMF-mediated biocontrol mechanism, although evidence is sparse in the literature (Jung et al., 2012). Current estimates indicate that the transfer of carbon from the host plant to the AMF varies between 4 and $20 \%$ of the total assimilated carbon (Hummer et al., 2011).

Treatments that involved subjecting the plants to a high pathogen level (4000 cyst nematode eggs) eliminated the improved growth, such as greater plant height and root length, seen in response to AMF (Figure 2 and Table 1), indicating that the presence of the high level of inoculum of the pathogen prevented the AMF response. These results are in line with other studies that claimed that the protection conferred by the AMF depends on the level of colonization and the specificity of the isolated AMF. The degree of improvement in tolerance of the host plant to the pathogen also depends on the degree of presence of the pathogen and the rate of association with the mycorrhizal fungus (Ceustermans et al., 2018; Chen et al., 2017; Harrier and Watson, 2004; Ruscitti et al., 2017).

The root system of the plants was $32.20 \%$ longer, on average, in the presence of AMFs (Figure 2). In addition to improving nutritional status, mycorrhizal plants generally show increased root growth and branching (Gamelero et al., 2010; Gutjahr \& Paszkowski, 2013). This factor can have a positive effect on the host plant, by counterbalancing the decrease in root branching caused by migratory endoparasitic nematodes. For sedentary endoparasitic nematodes, such as the cyst nematode, the zones of root elongation and the sites of lateral root formation are the preferred sites of penetration, probably because of the enhanced root exudation in these zones (Curtis et al., 2009).

According to Jung et al. (2012), a competition factor may be involved in the interaction between nematodes and AMFs. A competition for space may explain the fact that the number of female nematodes found in the root was $28.21 \%$ lower in the mycorrhizal plant than in the non-mycorrhizal plant, since the number of cysts in the soil was $20.65 \%$ higher in the presence of the AMF than in the absence of the fungus (Figure 2). The increase in the population density of the nematode cysts in the soil, as observed in this work, is also in agreement with the findings of Tylka (1991), who stated that the population density of the cyst nematode is generally higher in sites colonized by AMFs. These results support the suggestion that a reduction in the penetration of juveniles occurred in the roots of soybeans. 
Figure 2 - Effect of inoculation of the fungus Glomus etunicatum on the dry mass of the shoot (A), the root length (B), the number of Heterodera glycines female nematodes in the roots (C), and the number of cysts in the soil (D) surrounding the soybean plants at 50 days after fungal inoculation.
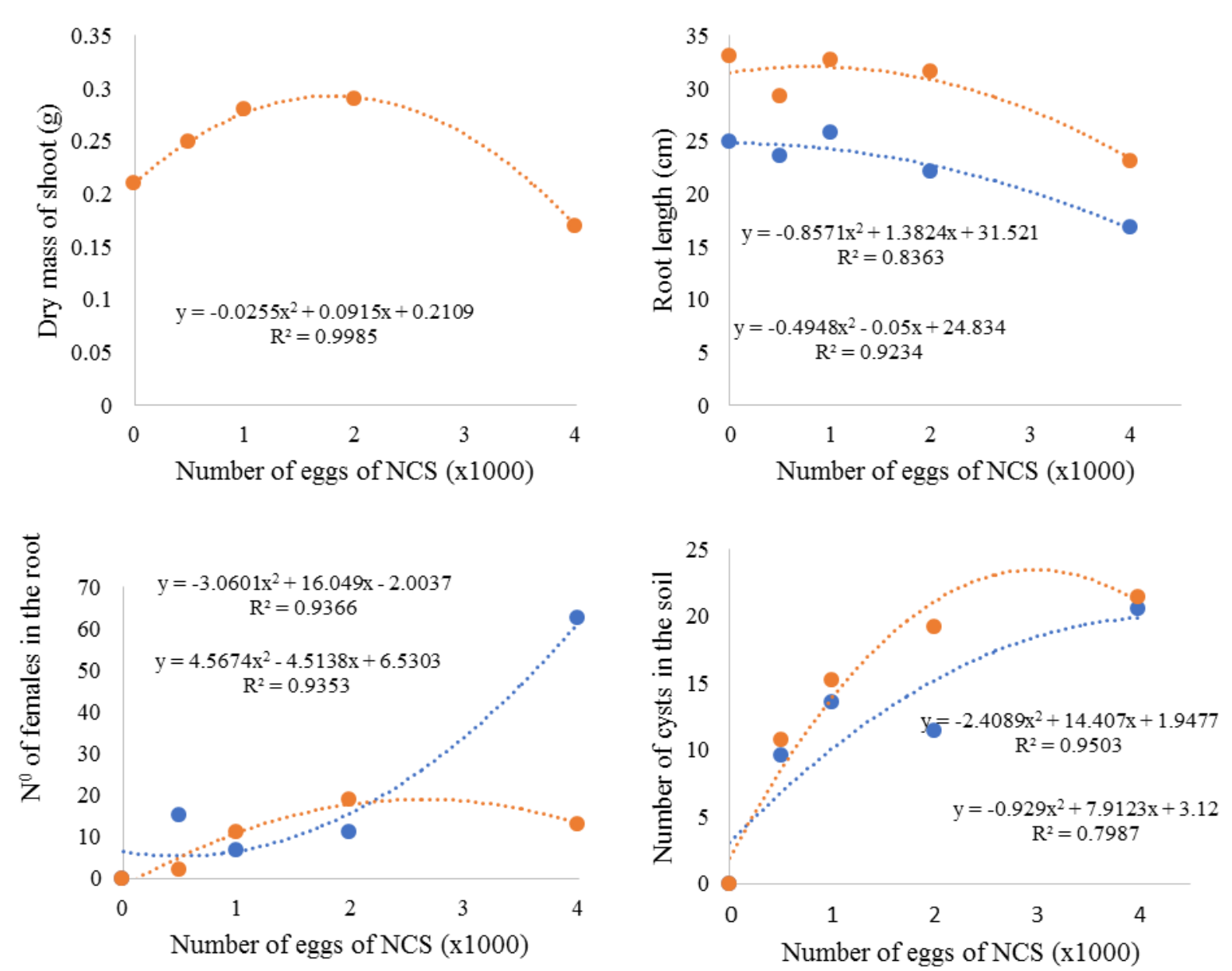

\section{- NCS NCS+FMA}

Source: Authors.

The negative effects on the nematode by the fungus are explained by the fact that mycorrhizal bushes are formed exclusively in the cortex, where the migratory endoparasitic nematodes also feed (Schouteden et al., 2015). In the case of sedentary endoparasites, such as the cyst nematode, this factor could be important only if the feeder cells extend into the cortex prior to the nematode inoculation (Schouteden et al., 2015). However, as mycorrhizal bushes are short-lived structures, distinguishing whether the AMF or the nematode colonized the same root first is difficult (Javot et al., 2011; Schouteden et al., 2015). The findings of the present study can neither confirm nor disprove that this effect occurred.

The mycorrhizal association may also affect the reproduction of nematodes by reducing oviposition and the number of individuals in the plant root system. This effect of AMF on nematode reproduction is considered to depend on a high percentage of root colonization by the mycorrhizal fungus (Cofcewicz et al., 2001). The observed reduction in the number of nematodes in the root, considering the greater number of cysts in the soil in the mycorrhizal plant (Figure 2), may be due to a reduction in the penetration of juveniles because of the competition factor. Alternatively, it may reflect a pathogenic effect of G. etunicatum on the reproduction of the cyst nematode, in agreement with other work in the literature (Hol \& Cook, 2005; 
Vos et al., 2012). The AMF G. etunicatum therefore appears to have good potential for the biocontrol of soybean cyst nematode (H. glycines, race 3 ) in soybean, thereby corroborating the initial hypothesis of the present study.

\section{Conclusion}

This study evaluated the potential of the mycorrhizal fungus Glomus etunicatum in the biological control of the cyst nematode (Heterodera glycines race 3) in soybean. Overall, the findings indicated that:

i) the presence of AMF G. etunicatum favors an increase in the length of roots and height of plants.

ii) the mycorrhizal fungus $G$. etunicatum reduces the number of female cyst nematode (H. glycines) is reduced in the presence of the mycorrhizal fungus G. etunicatum.

iii) the presence of the G. etunicatum improves the nutritional status of the plant.

iv) the presence of the G. etunicatum in soybean decreases the nematode penetration in root due to the competition for space between the organism species.

Our results suggest that the fungus acts indirectly to improve the nutritional status of the plant, thereby favoring better tolerance of the plant to the presence of the pathogen. Further studies may be carried out in order to verify the effect of the potential of G. etunicatum on the biological control of the NCS, considering its effect on the yield of the culture. In addition, studies are needed to elucidate the interaction between the NCS, the mycorrhizal fungus and the host plant at a physiological and biochemical level for a better understanding of the interaction process.

\section{Acknowledgments}

To the National Council for Scientific and Technological Development for the scholarship, Edson Campanhola Bortoluzzi fellowship 304676/2019-5 and Zaida Ines Antoniolli 305046/2018-7 and financial assistance.

\section{References}

Abad, P., Gouzy, J., Aury, J. M., Castagnone-Sereno, P., Danchin, E. G. J., Deleury, E. \& Wincker, P. (2008). Genome sequence of the metazoan plantparasitic nematode Meloidogyne incognita. Nature Biotechnology, 26, 909-915.

Alban, R., Guerrero, R. \& Toro, M. (2013). Interactions between a root-knot nematode (Meloidogyne exigua) and arbuscular mycorrhizae in coffee plant development (Coffea arabica). American Journal of Plant Sciences, 4(7), 19-23.

Alvarado-Herrejón, M., Larsen, J., Gavito, ME., Jaramillo-López, P. F., Vestberg, M., Martínez-Trujillo, M. \& Carreón-Abud, Y. (2019). Relation between arbuscular mycorrhizal fungi, root-lesion nematodes and soil characteristics in maize agroecosystems. Applied Soil Ecology, 135, 1-8.

Bartlem, D. G., Jones, M. G. K. \& Hammes, U. Z. (2014). Vascularization and nutriente delivery at root-knot nematode feeding sites in host roots. Journal of Experimental Botany, 65(7), 1789-1798.

Baum, C., El-Tohamy, W. \& Gruda, N. (2015). Increasing the productivity and product quality of vegetable crops using arbuscular mycorrhizal fungi: a review. Scientia Horticulturae, 187, 131-141.

Cameron, D., Neal, A., Van Wees, .S \& Ton, J. (2013). Mycorrhiza-induced resistence: more than the sum of its parts? Trends in Plant Science, $18,539-545$.

Ceustermans, A., Hemelrijck, V. W., Campenhout, J.V. \& Bylemans, D. (2018). Effect of Arbuscular Mycorrhizal Fungi on Pratylenchus penetrans Infestation in Apple Seedlings under Greenhouse Conditions. Pathogens, 7(76), 1-10.

Chen, S., Zhao, H., Zoul, C., Li, Y., Chen, Y., Wang, Z., Jiang, Y., Liu, A., Zhao, P., Wang, Z. \& Ahammed, G. J. (2017). Combined Inoculation with Multiple Arbuscular Mycorrhizal Fungi Improves Growth, Nutrient Uptake and Photosynthesis in Cucumber Seedlings. Frontiers Microbiology, 8.

Cofcewicz, E. T., Medeiros, C. A. B., Carneiro, R. M. D. G. \& Pierobon, C. R. (2001). Interaction of arbusuclar mycorrhizal fungi Glomus etunicatum and Gigaspora margarita and root-knot nematode Meloidogyne incognita in tomato. Fitopatologia Brasileira, 26(1), 65-70.

Cotton, J. A., Lilley, C. J., Jones, L. M.,Kikuchi, T., Reid, A. J., Thorpe, P., Tsai, I. J., Beasley, H. Blok, V., Cock, P. J. A., Akker, S. E den, Holroyd, N., Hunt, M., Mantelin, S., Naghra, H., Pain, A., Palomares-Rius, J. E., Zarowiecki, M., Berriman, M.,Jones, J. T. \& Urwin, P. E. (2014). The genome and lifestage specific transcriptomes of Globodera pallida elucidate Key aspects of plant parasitism by a cyst nematode. Genome Biology, $15,1-17$. 
Curtis, R. H. C., Robinson, A. F. \& Perry, R. N. (2009). Hatch and host location. In: Perry, R. N., Moens, M. \& Starr, J. L. (eds) Root-knot nematodes. CAB International, Wallingford, 139-162.

De Coninck, B., Timmermans, P., Vos, C., Cammue, B. P. A. \& Kazan, K. (2015). What lies beneath: belowground defense strategies in plants. Trends in Plant Science, 20, 91-101.

Dehne, H. W. (1982). Interaction between vesicular-arbuscular mycorrhizal fungi and plant pathogens. Phytopathology, 72, 1115-1119.

Ferraz, L. \& Brown, D. (2002). An Introduction to Nematodes. Plant Nematology.

Gamalero, E., Pivato, B., Bona, E., Copetta, A., Avidano, L., Lingua, G. \& Berta, G. (2010). Interactions between a fluorescent pseudomonad, an arbuscular mycorrhizal fungus and a hypovirulent isolate of Rhizoctonia solani affect plant growth and root architecture of tomato plants. Plant Biosystems, 144(3), 582591.

Gheysen, G. \& Mitchum, M. G. (2011). How nematodes manipulate plant development pathways for infection. Current Opinion in Plant Biology, 14(4), 415421.

Gianinazzi, S., Gollote, A., Binet, M. Tuinen, Van, D., Redecker, D. \& Wipf, D. (2010). Agroecology: the key role of arbuscular mycorrhizas in ecosystem services. Mycorrhiza, 20(8), 519-530.

Grabau, Z. J. \& Chen, S. (2020). Determining the role of plant-parasitic nematodes in the corn-soybean crop rotation yield effect using nematicide application: I. Corn. Agronomy Journal. 108, 782-793.

Guo, W., Chen, J. S., Zhang, F., Ze, Y. L. I., Chen, H. F., Zhang, C., Chen, L. I. M., Song, L. Y., Rong, L., Dong, C., Qing, N. H., Shui, L. C., Zhi, H. S., Zhong, L. Y., Xiao, J. Z., De Z. Q., Qing, B. Y., Wen, J. D., Xin, A. Z., Xin, J. S. \& Yong, Q. J. (2020). Caracterization of Pingliang xiaoheidou (ZDD 11047), a soybean variety with resistance to soybean cyst nematode Heterodera glycines. Plant Molecular Biology.

Gutjahra, C. \& Paszkowski, U. (2013). Multiple control levels of root system remodeling in arbuscular mycorrhizal symbiosis. Frontiers Plant Science, $4(204), 1-8$

Haarith, D., Bushley, K. E. \& Chen, S. (2020). Fungal communities associated with Heterodera glycines and their potential in biological control: a current update. The Journal of Nematology, 52, 1-17.

Hammer, E. C., Pallon, J., Wallander, H. \& Olsson, P. A. (2011). Tit for tat? A mycorrhizal fungus accumulates phosphorus under low plant carbon availability. FEMS Microbiology Ecology, 76(2), 236-244.

Harrier, L. A. \& Watson, C. A. (2004). The potential role of arbuscular mycorrhizal (AM) fungi in the bioprotection of plants against soil-borne pathogens in organic and/or other sustainable farming systems. Pest Management Science 60(2), 149-57.

Hol, W. H. G. \& Cook, R. (2005). Na overview of arbuscular mycorrhizal fungi-nematode interactions. Basic and Applied Ecology, 6(6), 489-503.

Jones, J. T., Haegeman, A., Danchin, E. G. J., Gaur, H. S., Helder, J., Jones, M. G. K., Kikuchi, T., Manzanilla-López, R., Palomares-Rius, J. E., Wesemael, W. M. L. e Perry, R. N. (2013). Top 10 plant-parasitic nematodes in molecular plant pathology. Molecular Plant Pathology, 14, 946-961.

Junh, S. C., Martinez-Medina, A., Lopez-Raez, J. A. \& Pozo, M. J. (2012). Mycorrhiza-induced resistance and priming of plant defenses. Journal of Chemical Ecology, 38, 651-664.

Kellam, M. K. \& Schenck, N. C. (1980). Interaction between a vesicular-arbuscular mycorrhizal fungus and root-knot nematode on soybean. Phytopathology, 70, 293-296.

Khalil, S., Loynachan, T. E. \& McNabb, H. S. J. (1992). Colonization of soybean by mycorrhizal fungi and spore populations in Iowa soils. Agronomy Journal, 84, 832-836.

Khalil, S. Loynachan, T. E. \& Tabatabai, M. A. (1999). Plant determinants of mycorrhizal dependency in soybean. Agronomy Journal, 91, $135-141$.

Koenning, S. R. \& Wrather, J. A. (2018). Suppression of soybean yield potential in the continental United States from plant diseases estimated from 2006 to 2009. Plant Health Progress.

Ma, Y. Y., Li, Y. L., Isi, H. X., Guo, Q. \& Xue, Q. H. (2017). Effects of two strains of Streptomyces on root-zone microbes and nematodes for biocontrol of root-knot nematode disease in tomato. Applied Soil Ecology. 112, 34-41.

Nicol, J. M., Turner, S. J., Coyne, D. L., Nijs, L. D., Hockland, S. \& Maafi, Z. T. (2011). Current nematode threats to world agriculture. In: Jones, J., Gheysen G., Fenoll C. (Eds). Genomics and Molecular Genetics of Plant-Nematode Interactions. Springer, 21-43.

Nimnoia, P. \& Ruanpanun, P. (2020). Suppression of root-knot nematode and plant growth promotion of chili (Capsicum flutescens L.) using co-inoculation of Streptomyces spp. Biological Control, 145, 104-244.

Parniske, M. (2008). Arbuscular mycorrhiza: the mother of plant root endosymbioses. Nature Reviews Microbiology, 6, 763-775.

Perry, R. N \& Moens, M. (2011). Introduction to plant -parasitic nematodes, modes of parasitismo. In: Jones, J., Gheysen G., Fenoll C. (Eds). Genomics and Molecular Genetics of Plant-Nematode Interactions. Springer,320.

Pozo, M. \& Azcón-Aguilar, C. (2007). Unraveling mycorrhiza-induced resistence. Current Opinion in Plant Biology, 10(4), 393-398.

Rasmussen, P.U., Chareesri, A., Neilson, R., Bennett, A. E. \& Tack, A. J. M. (2019). The impact of dispersal, plant genotype and nematodes on arbuscular mycorrhizal fungal colonization. Soil Biology and Biochemistry, 132, 28-35. 
Ross, J. P. (1971). Effect of phosphate fertilization on yeld of mycorrhizal and nonmycorrhizal soybeans. Phytopathology, 61, 1400-1403.

Ruanpanun, P. \& Chamswarng, C. (2016). Potential of actinomycetes isolated from earthworm castings in controlling root-knot nematode Meloidogyne incognita. Journal of General Plant Pathology, 82, 43-50.

Ruscitti, M., Arango, M. \& Beltrano, J. (2017). Improvement of copper stress tolerance in pepper plants (Capsicum annuum L.) by inoculation with arbuscular mycorrhizal fungi. Theoretical and Experimental Plant Physiology, 29, 37-49.

Safir, G. R., Boyer, J. S. \& Gerdemann, J. W. (1972). Nutrient status and mycorrhizal enhancement of water transport in soybean. Plant Physiology, 49, 700703.

Schmutz, J., Cannon, S. B., Schlueter, J., Ma, J., Mitros, T., Nelson, W., Hyten, D. L., Song, Q., Thelen, J. J., Cheng, J., Xu, D., Hellsten, U., May, G. D., Yu, Y., Sakurai, T., Umezawa, T., Bhattacharyya, M. K., Sandhu, D., Valliyodan, B., Lindquist, E., Peto, M., Grant, D., Shu, S., Goodstein, D., Barry, K., FutrellGriggs, M., Abernathy, B., Du, J.,Tian, Z., Zhu, L., Gill, N., Joshi, T., Libault, M., Sethuraman, A., Zhang, X., Shinozaki, K., Nguyen17, H. T., Wing, R. A., Cregan, P., Specht, J., Grimwood, J., Rokhsar, D.,Stacey, G., Shoemaker, R. C. \& Scott, A. J. (2010). Genome sequence of the palaeopolyploid soybean. Nature, 463, 178-183.

Schouteden, N., Waele, D. D., Panis, B. \& Vos, C. M. (2015). Arbuscular mycorrhhizal fungi for the biocontrol of plant-parasitic nematodes: A review of the mechanism involved. Frontiers in Microbiology, 6, 1-12.

Silveira, D. T. \& Códova, F. P. (2009). A pesquisa científica. In: Gerhardt, T. A. \& Silveira, D. T. (org). Métodos de pesquisa. SEAD/UFRGS.

Singh, L. P., Gill, S. S. \& Tuteja, N. (2011). Unraveling the role of fungal symbionts in plan abiotic stress tolerance. Plant Signaling \& Behavior, v. 6, 175191.

Sohrabi, F., Sheikholeslami, M., Heydari, R., Rezaee, S. \& Sharif, R. (2020). Investigating the efect of Glomus mosseae, Bacillus subtilis and Trichoderma harzianum on plant growth and controlling Meloidogyne javanica in tomato. Indian Phytopathology, 73 , Páginas293-300

Strom, N., Hu, W., Haarith, D., Chen, S. \& Bushley, K. (2020). Interactions between soil properties, fungal communities, the soybean cyst nematode, and crop yield under continuous corn and soybean monoculture. Applied Soil Ecology, 147, 1-14.

Tihohod, D, \& Santos, J. N. (1993). Heterodera glycines: Novo nematóide da soja no Brasil. Detecção e medidas preventivas. FUNEP, 23.

Todd, T. C., Winkler, H. E. \& Wilson, G. W. T. (2001). Interaction of Heterodera glycines and Glomus mosseae on Soybean. Journal of Nematology, 33, 306310 .

Toumi, F., Waeyenberge, L., Viaene, N., Dababat, A., Nicol, J., Ogbonnava, F. \& Moens, M. (2018). Cereal cyst nematodes: importance, distribution, identification, quantification, and control. European Journal of Plant Pathology. 150, 1-20.

Tylka, G. L., Hussey, R. S. \& Roncadori, R. W. (1991). Interactions of vesicular-arbuscular mycorrhyzal fungi, phophoros, and Heterodera glycines on soybean. Journal of Nematology, 23(1), 122-133.

Vos, C. M., Yang, Y., Coninck, B. D. \& Cammue, B. P. A. (2014). Fungal (-like) biocontrol organisms in tomato disease control. Biological Control, 74, 6581.

Vos, C. M., Tesfahun, A. N., Panis, B., Waele, D. D. \& Elsen, A. (2012). Arbuscular mycorrhizal fungi induce systemic resistence in tomato against the sedentary nematode Meloidogyne incógnita and the migratory nematode Pratylenchus penetrans. Applied Soil Ecology, 61, 1-6.

Wesemael, W. M. L., Viene, N. \& Moens, M. (2011). Root-knot nematodes (Meloidogyne spp.) in Europe. Nematology, 13(1), 3-16.

Whipps, J. M. (2004). Prospects and limitations for mycorrhizas in biocontrol of root pathogens. Canadian Journal Botany, 82(8), $1198-1227$.

Winkler, H. E., Hetrick, B. A. \& Todd, T. C. (1994). Interactions of Heterodera glycines, Macrophomina phaseolina, and mycorrhizal fungi on soybean in Kansas. Journal of Nematology, 26, 675-682.

Wu, H. Y., He, Q., Liu, J. J. Luo, J. \& Peng, D. L. (2014). Occurrence and development of the cereal cyst nematode (Heterodera avenae) in Shandong, China. Plant Disease Journal, 98, 1654-1660. 